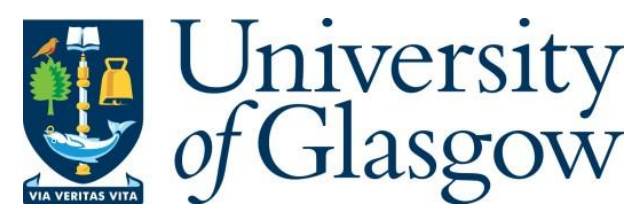

Conti-Brown, P. and Vanatta, S. H. (2020) The logic and legitimacy of bank supervision: the case of the bank holiday of 1933. Business History Review, (Accepted for Publication).

There may be differences between this version and the published version. You are advised to consult the publisher's version if you wish to cite from it.

$\underline{\text { http://eprints.gla.ac.uk/223788/ }}$

Deposited on: 5 October 2020

Enlighten - Research publications by members of the University of Glasgow http://eprints.gla.ac.uk 


\title{
The Logic and Legitimacy of Bank Supervision: The Case of the Bank Holiday of 1933
}

Peter Conti-Brown, The Wharton School of the University of Pennsylvania, The Brookings Institution

Sean H. Vanatta, University of Glasgow

\begin{abstract}
The U.S. banking holiday of March 1933 was a pivotal event in $20^{\text {th }}$ century political and economic history. After closing the nation's banks for nine days, the newly inaugurated Franklin D. Roosevelt administration restarted the banking system as the first step toward national recovery from the global Great Depression. In the conventional narrative, the holiday succeeded because Roosevelt used his political talents to restore public confidence in the nation's banks. Such accounts, however, say virtually nothing about what happened during the holiday itself. In this article, we reinterpret the banking crises of the 1930 s and the 1933 holiday through the lens of bank supervision, the continuous oversight of commercial banks by government officials. Through the 1930 os banking crises, federal supervisors identified troubled banks but could not act to close them. Roosevelt empowered supervisors to act decisively during the holiday. By closing some banks, supervisors made credible Roosevelt's claims that banks which reopened were sound. Thus, the union of FDR's political skills with the technical judgement of bank supervisors was the key to the solving the banking crisis. Neither could stand alone, and both together were the vital precondition for further economic reforms-including devaluing the dollar-and with them, Roosevelt's New Deal.
\end{abstract}

\footnotetext{
* The authors would like to thank the following friends and colleagues for their helpful comments: Dan Awrey, Ben Bernanke, Katlyn Carter, Brian Feinstein, Dick Herring, Eric Hilt, Harold James, Kate Judge, Mike Klausner, Kevin Kruse, Yair Listokin, Jon Macey, Paul Mahoney, Eric Monnet, John Morley, Eric Rauchway, George Selgin, David Zaring, and Julian Zelizer. We would like to give special thanks to Judge Glock, whose insights and source recommendations proved especially useful, and Walter Friedman and the BHR's anonymous reviewers for their critical insights.
} 


\section{Introduction}

"I want to talk for a few minutes with the people of the United States about banking." With that line, Franklin D. Roosevelt began one of the most ambitious political experiments in U.S. history. Historians know the story well. Broadcast over radio to a nervous but hopeful public in March 1933, Roosevelt used the first of his "fireside chats" to reassure the nation that his administration was solving the banking and economic crisis. Between January 1930 and March 1933, 5,722 distressed US banks had merged or permanently closed. In the two months preceding Roosevelt's inauguration, more than 40 states shuttered their banks to prevent further failures. In avuncular tones, the new president explained how vital banking was to "keep the wheels of industry and of agriculture turning." He detailed why he had declared a national bank holiday, closing all the nation's banks as "the first step in the Government's reconstruction of our financial and economic fabric." And he reassured his listeners that these bold efforts would ensure that "No sound bank is a dollar worse off than it was when it closed its doors last Monday.”

The stakes could not have been higher. In the early 1930s, banking and currency crises spread economic contagion across the global economy, bringing violent political upheaval in their wake. Roosevelt understood that if the banking crisis remained unchecked, the United States could well suffer a similar fate. "The success of our whole great national program depends," Roosevelt concluded, "upon the cooperation of the public." This statement implicated not only the New Deal, but liberal democracy itself. If the bank holiday failed, there was no assurance that the nation could succeed. ${ }^{2}$

The holiday did succeed, and with it the financial recovery, the New Deal, and the American experiment. Although further reforms-most importantly the devaluation of the dollar through the abandonment of the gold standard-would be necessary to revive the economy, the holiday was the vital precondition for all further action. Indeed, Roosevelt's banking policy and currency policy were inextricably linked; to devalue the dollar, his administration first had to save the banks. Only then would he have the credibility to transform the currency. Only then could the financial system function in a world without gold. 3

\footnotetext{
${ }^{1}$ Gary Richardson, “Categories and Causes of Bank Distress During the Great Depression, 1929-1933: The Illiquidity versus Insolvency Debate Revisited,” Explorations in Economic History 44, no. 4 (October 2007): 593; Hugh Rockoff, "The Meaning of Money in the Great Depression," NBER Historical Working Papers, no. 52 (December 1993): 36-37, https://www.nber.org/papers/ho052; Franklin D. Roosevelt, "Fireside Chat on Banking," 12 Mar. 1933 , The American Presidency Project, eds. Gerhard Peters and John T. Woolley, https://www.presidency.ucsb.edu/documents/fireside-chat-banking.

${ }^{2}$ Roosevelt, "Fireside Chat on Banking."

3 Eric Rauchway argues that these actions were simultaneous and that devaluation took precedence (The Money Makers: How Roosevelt and Keynes Ended the Depression, Defeated Fascism, and Secured a Prosperous Peace [New York, 2015], 19-72). Many economic historians disagree, arguing that the devaluation stands alone in its impact on recovery. See Peter Temin \& Barrie A. Wigmore, "The End of One Big Deflation," Explorations in Economic
} 
Political historians have long understood the holiday as central to Roosevelt's transition to power, but their emphasis-writing soon after 1933 and continuing to the present-has been on the drama of high politics and the confidence Roosevelt instilled with his soaring presidential rhetoric. This was a Rooseveltian masterstroke, the story goes. It performed the same function, historians Charles Beard and George Smith put it soon after the events, as "a slap in the face for a person gripped by unreasoning hysteria." "The closing of the banks," wrote Arthur Schlesinger in his history of the New Deal, "seemed to give the long economic descent the punctuation of a full stop, as if this were the bottom and hereafter things could only turn upward." The conception that it was, as one economic historian phrased it, "FDR's Bank holiday," is also ubiquitous in the economic and political literature. As Ben Bernanke archly wrote, "It might be argued that [the holiday] . . . was the only major New Deal program that successfully promoted economic recovery."4

This article challenges the simple equation of Roosevelt's political talents and the holiday's success by focusing on the holiday itself. What actually happened during those fateful days, and what preceded it? How did the government ensure, as Roosevelt promised, that "[n]o sound bank is a dollar worse off?" This article tells that story. In it, we revisit the period of 1929-1933. For the "comparatively few who underst[ood] the mechanics of banking," in FDR's words, the holiday was not only a moment of high presidential authority, but also the mobilization of something more mundane: bank supervision. 5

Bank supervision, we argue, was a defining ingredient in the success of the holiday-and with it, the coming New Deal. A mode of financial governance then largely specific to the United States, supervision entailed the continuous oversight of commercial banking firms by government officials. Supervisors had files on the banks; during the holiday they used them to restore life or pronounce death on the thousands of individual firms subjected to this process. Although their work was frantic and bleary-eyed, inhibited by imperfect information and constrained by politics, it was essential to placing the financial system on a sound footing. Supervision, we argue, provided the technocratic foundation for Roosevelt's lofty rhetoric, grounding his promises in the expertise of long-serving federal bureaucrats. The holiday, meanwhile, gave supervisors new authority to

History, 27, 483-502 (1990); Scott Sumner, The Midas Paradox: Financial Markets, Government Policy Shocks, and the Great Depression (New York, 2015).

4 Charles A. Beard and George E. Smith, The Old Deal and the New (New York, 1940), 78; Arthur M. Schlesinger, Jr., The Age of Roosevelt: The Coming of the New Deal (New York, 1959), 6; William L. Silber, "Why Did FDR's Bank Holiday Succeed?," Federal Reserve Bank of New York Economic Policy Review (July 2009): 19-30; Ben S. Bernanke, "Nonmonetary Effects of the Financial Crisis in the Propagation of the Great Depression," American Economic Review V. 73, no 3 (June 1983): 272. But cf. Susan E. Kennedy, The Banking Crisis of 1933 (Louisville, 1973).

5 Roosevelt, "Fireside Chat on Banking." 
act decisively. Roosevelt enabled supervisors to close troubled banks; in closing them, supervisors assured the public that the banks which did reopen were sound.

The holiday's particular combination of political authority and supervisory decisiveness stood in stark contrast to what had come before. Roosevelt's predecessor, Herbert Hoover, had likewise employed the full power of presidential speech to restore public confidence. He had simultaneously prescribed leniency among federal supervisors, urging them not to close troubled banks. The brute fact of cascading bank failures, however, undermined supervisory credibility, and with it, the efficacy of Hoover's bully pulpit. Without the technical work of bank supervision, invested with political authority to act, Roosevelt's stirring oratory would likely have met the same fate. ${ }^{6}$

The combination of the two factors-supervision plus political backing-enabled Roosevelt to restore confidence in the banking system and prepare the way for further economic reforms. The political support was not merely rhetorical, although the effect of the public mood in response to Roosevelt was very important. Roosevelt and eventually Congress also stood behind supervisors' assessments, committing to backstopping surviving banks. Once supervisors judged a bank sound, the administration stood ready to make it so. This guarantee was implicit and explicit, including loan guarantees by the Treasury and reputational guarantees by the Administration. Within months, the informality of these guarantees gave way to the new regime that the holiday created: a system of federal deposit insurance that continues to this day. 7

This argument stands in contrast to detractors, like economic historian Barry Eichengreen, who view holiday examination as a mere "urban legend." It was "hardly possible," Eichengreen argues, "to conduct careful inspections of each and every financial institution." Earlier historians agreed. Frederick Lewis Allen, in his 1939 history of the early New Deal, viewed Roosevelt's triumphal rhetoric as without substance, backed only by FDR's confidence and the people's faithful acceptance of that confidence. "The banks opened without...renewed panic...[but] might not have done so had the people realized that it was impossible, in a few days, to separate the sound banks from the unsound."8

Eichengreen and Allen were right, of course, that within the short period of the holiday it was impossible to make perfect, objective, globally consistent assessments of the entire system and the individual banks within it. But such an expectation misunderstands supervision as a mode

\footnotetext{
${ }^{6}$ Roosevelt, "Fireside Chat on Banking;" Craig O. Brown and I. Serdar Dinç, "Too Many to Fail? Evidence of Regulatory Forbearance When the Banking Sector Is Weak," Review of Financial Studies 24 no. 4 (April 2011): 1378-1405

7 This argument is similar to Silber's in "Why Did FDR's Bank Holiday Succeed?," Federal Reserve Bank of New York Economic Policy Review (July 2009): 19-30. Silber, however, mostly ignores the role of supervision in this guarantee system.

8 Barry Eichengreen Hall of Mirrors: The Great Depression, and the Uses - and Misuses - of History (New York, 2015), 296; Frederick L. Allen, Only Yesterday: An Informal History of the Nineteen-Twenties (New York, 1939 ), 110.
} 
of governance, a misunderstanding this article seeks to correct. Supervision was iterative, not isolated. It combined a set of imperfect, discretionary, and sometimes inconsistent toolsincluding accounting, banking, management consulting, and policing-to gather information and guide bank behavior. A form of what historian Brian Balogh has called "associational governance," supervision was, by design, inhibited by weak enforcement powers fractured among competing state and federal agencies. It was at once forward- and backward-looking, coercive and cooperative, bound by common rules and practiced through individual judgement. These boundaries on federal power, while frustrating to oversight officials, undergirded the operational legitimacy of supervisory institutions in normal times-but handicapped these same institutions in moments of crisis. 9

By emphasizing supervision's centrality to the holiday's success in the United States, our argument raises important questions about the role of supervision within the wider context of the global Great Depression. Here, we share the view, advanced by Eichengreen and others, that fears of devaluation contributed to the March 1933 banking panic, and that dollar devaluation, part of a global turn away from the "golden fetters" of the interwar era, was ultimately necessary for U.S. recovery. We maintain, however, that supervisors first had to ensure-and effectively guaranteebank solvency before devaluation could be politically legitimate or institutionally viable. We also recognize that the U.S. supervisory system was globally exceptional. Most industrial nations instituted supervisory regimes only after the 1930 s crises, relying on bank audits until well into the twentieth century. We do not take up the comparative causal argument here, but this exceptionalism invites such analysis: bank supervision, we believe, aided the U.S. in containing a bank panic that in other jurisdictions extended throughout the 1930s. ${ }^{10}$

To be clear, supervision alone could not summon the legitimacy to forestall bank runs, before or after Roosevelt's inauguration. But however wide his mandate, Roosevelt also lacked the ability to talk away the crisis. Instead, governmental actions during the holiday became legitimate because political commitments and supervisory expertise created a self-perpetuating cycle of legitimacy. Even the bankers recognized it as such. "Only by prompt and favorable" intervention

\footnotetext{
9 Brian Balogh, The Associational State: American Governance in the Twentieth Century (Philadelphia, 2015), 23-30. ${ }^{10}$ Harold James, The End of Globalization: Lessons from the Great Depression (Cambridge, MA, 2002), 52-101; Barry Eichengreen, Golden Fetters: The Gold Standard and the Great Depression, 1919-1939 (New York: 1992), 326-331; Barrie A. Wigmore, "Was the Bank Holiday of 1933 a Run on the Dollar Rather than a Run on the Banks?" Journal of Economic History 47, no. 3 (Sept. 1987): 739-756; Eugene N. White, "Lessons From American Bank Supervision From The Nineteenth Century To The Great Depression," in Macroprudential Regulatory Policies: The New Road to Financial Stability? Stijn Claessens, Douglas D. Evanoff, George G. Kaufman, and Laura E Kodres, eds. (Hackensack, NJ, 2012), 41-61. For the global context, see Richard S. Grossman, Unsettled Account: The Evolution of Banking in the Industrialized World since 1800 (Princeton, 2010), 162-167, 221-222; Eiji Hotori and Mikael Wendschlag, "The Formalization of Bank Supervision in Japan and Sweden," Social Science Japan Journal 22, no. 2 (Summer 2019): 212, 215; Patrice Baubeau, Eric Monnet, Angelo Riva, and Stefano Ungaro, "Flight-to-Safety and the Credit Crunch: A New History of the Banking Crises in France during the Great Depression," Economic History Review (forthcoming).
} 
by bank supervisors, a group of shuttered North Carolina banks urged the Comptroller of the Currency in September 1933, "can the depositors of Paige Trust Company and the people in the communities served by this bank realize the full benefits of the "New Deal." Associating the work of bank supervision with the political moment was intentional: whatever hostilities bankers felt toward their examiners or Roosevelt's political revolution before the crisis, they knew how central examination and FDR's New Deal were, together, to their recovery. ${ }^{11}$

The article proceeds as follows. First, we describe federal bank supervision as it existed before the banking crisis. In these years, federal officials employed a distinct set of oversight tools that balanced strict rule enforcement with significant discretion, the latter sometimes exercised on the ground by field examiners and sometimes by officials-including politicians-higher up in the hierarchy. We then show how, as the banking crisis deepened from 1930 through Roosevelt's inauguration in March 1933, Hoover administration officials embraced a policy of supervisory forbearance, keeping banks open by extending their discretion past the point of plausibility. When the crash came, however, it was these same officials, now working with Roosevelt's incoming staff, who devised a rescue plan that mobilized supervisory knowledge, not only, as Roosevelt promised, to open sound banks, but, as importantly, to keep unsound banks closed. By declaring some banks unfit to open, bank supervisors boldly broke with past expectations and created, with Roosevelt's rhetoric, the conditions for the New Deal.

\section{The Landscape of Supervisory Authority and the Coming Crisis}

The U.S. banking system in 1933 was uniquely byzantine in its institutional and supervisory complexity. Individual states and the federal government each maintained the authority to charter and oversee banking institutions, power held nationally by the Comptroller of the Currency (since 1863) and locally by state-level banking departments (from the 1820s). Overlaying this structure was the new Federal Reserve System, founded in 1913. The Fed exercised authority over all nationally-chartered banks, as well as the state-member banks which chose to join the system. Although tangled, the U.S. supervisory structure was comparatively deep-rooted. With the exception of Sweden (1909) and Japan (1916), most developed countries formalized bank supervision only after the 1930 s banking crises. ${ }^{12}$

Governed by this fractured oversight regime, the U.S. banking system was at once dynamic and fragile. Chartering competition among state and federal authorities reduced barriers to entry

\footnotetext{
${ }^{11}$ KCR to Comptroller of the Currency, September 7, 1933, DC-AA-1933 folder, box 1, Records Relating to the Banking Holiday, Records of the Office of the Comptroller of the Currency, RG 101, NARA II, Collage Park, MD.

${ }_{12}$ Eugene Nelson White, The Regulation and Reform of the American Banking System, 190o-1929 (Princeton, 1983), 126-187, esp. 132; Grossman, Unsettled Account, 162-167, 221-222; Hotori and Wendschlag, "Formalization of Bank Supervision in Japan and Sweden," 212, 215.
} 
beginning in the late-nineteenth century, so that by 1920 , the nation was blanketed by nearly 30,ooo individual banks. Most of these institutions were small, under-capitalized, geographically confined, and rural; they did not fare well during the long agricultural depression that followed the end of World War I. Meanwhile, commercial bankers in industrial cities and at the booming periphery participated enthusiastically in the era's economic exuberance. They also grew through new branch networks and holding companies, expansion in scale and scope which offered stability or speculative opportunity-depending on the bank-and in all cases made government oversight more difficult. ${ }^{13}$

Table 1: Banks by Charter and Assets, 1890-1925

\begin{tabular}{|l|l|l|l|l|l|l|}
\hline Year & $\begin{array}{l}\text { National } \\
\text { Banks }\end{array}$ & State Banks & $\begin{array}{l}\text { National Bank } \\
\text { Assets } \\
\text { (millions) }\end{array}$ & $\begin{array}{l}\text { State Bank } \\
\text { Assets } \\
\text { (millions) }\end{array}$ & $\begin{array}{l}\text { Av. Nat } \\
\text { Bank assets } \\
\text { (millions) }\end{array}$ \\
\hline 1890 & 3,484 & 2,101 & $\$ 3,484$ & $\$ 871$ & $\$ 1$ \\
\hline 1895 & 3,715 & 3,774 & $\$ 3,471$ & $\$ 1,147$ & $\$ .93$ \\
\hline 1900 & 3,731 & 4,369 & $\$ 4,944$ & $\$ 1,756$ & $\$ 1.33$ \\
\hline 1905 & 5,664 & 7,794 & $\$ 7,325$ & $\$ 3,190$ & $\$ 1.29$ \\
\hline 1910 & 7,138 & 12,166 & $\$ 9,892$ & $\$ 3,694$ & $\$ 1.38$ \\
\hline 1915 & 7,597 & 18,277 & $\$ 8,817$ & $\$ 9,176$ & $\$ 2.41$ \\
\hline 1920 & 8,024 & 21,062 & $\$ 17,159$ & $\$ 18,955$ & $\$ 2.62$ \\
\hline 1925 & 8,066 & 19,792 & $\$ 19,912$ & $\$ 24,551$ & $\$ 2.45$ \\
\hline
\end{tabular}

Source: White, Regulation and Reform, 12-13, 132 (For 1915 and after, deposits substituted for assets).

The federal supervisory structure through which government agents oversaw these changes was still, at this stage, seeking equilibrium. Bank supervision relied primarily on examination, a legal concept derived from visitorial powers, "an exercise of sovereignty," one federal examiner explained, "for the purpose of determining that the charter powers granted were not abused." Although Congress created supervision initially with varied concerns, including those relevant to monetary policy, through steady institutional evolution federal supervisors developed a broader set of norms and practices aimed at maintaining sound banks. Whatever the

13 Kris James Mitchener, "Bank Supervision, Regulation, and Instability during the Great Depression," Journal of Economic History 65, no. 1 (March 2005): 152-185; Branch, Chain, and Group Banking, 71 Cong. V. 1, Part I, 28-32, 68-70 (Statement of Comptroller James Pole). In theory, branching promotes bank stability. Scholars debate whether it did so in fact during the depression (Mark Carlson and Kris James Mitchener, "Branch Banking as a Device for Discipline: Competition and Bank Survivorship during the Great Depression," Journal of Political Economy 117, no. 2 [April 2009]: 165-210). 
legal structure, supervision was fundamentally flexible; it relied on the face-to-face interaction of bank officers and federal officials and necessarily fluctuated between corrective and cooperative, formalist and discretionary, as circumstances warranted. Above all, Comptroller Henry Dawes observed in 1923, "the unadvertised but chief function of the office of the Comptroller of the Currency...is keeping the banks from failing."'14

In practice, despite supervisors' flexibility, they were constrained in their ability to change bank behavior. The Comptroller had the broadest authority and was charged with overseeing the entire life cycle of a national bank, through birth, life, and potentially death. Each stage was embodied in a corresponding set of tools, chartering (birth), examination and call reporting (life), and receivership or liquidation (death). Law and practice diverged widely in each stage. Chartering required by rule that shareholders supply capital; it relied in practice on the Comptroller's judgement of the managerial capacity of bank officers and their business prospects. Likewise, irregular "call reports," sworn statements of a bank's condition provided to the Comptroller and published in the local newspaper, offered a seemingly objective, rules-based system of public surveillance. Asset values banks published, though, were fundamentally matters of judgement; they reflected not some objective economic reality but a highly subjective one, aimed at securing the Comptroller's endorsement and maintaining public confidence.

Of these four approaches-chartering, private examination, public call reports, and liquidation-examination was the most active tool in the supervisor's kit. By the early 1930, the Comptroller employed 191 national bank examiners, divided among the 12 Federal Reserve Districts. At least twice a year, an examiner inspected each national bank, determining most basically whether the bank was legally compliant and financially solvent. Through this process, the examiner collected vast information about the bank's assets and liabilities, the quality of bank management, its loan collateral and collection practices, down even to the make and model of the bank's safe. The examination report went first to the District Chief National Bank Examiner, who maintained an office and files at the Federal Reserve bank, and then on to the Comptroller in

\footnotetext{
14 Robert F. Leonard, "Supervision of the Commercial Banking System," in Banking Studies, E. A. Goldenweiser, Elliot Thurston, and Bray Hammond, eds. (Baltimore, 1941), 190; Bray Hammond, Banks and Politics in America: From the Revolution to the Civil War (Princeton, 1957), 187; Ross M. Robertson, The Comptroller and Bank Supervision: A Historical Appraisal (Washington, DC, 1968), 24-25; Leo H. Paulger, "Policy and Procedure in Bank Examination," in Banking Studies, 217; Comptroller of the Currency, Annual Report of the Comptroller of the Currency (1923), 20. For more on the historical development and legal status of visitorial rights, see Judge Glock, "The Forgotten Visitorial Power: The Origins of Administrative Subpoenas and Modern Regulation," Review of Banking and Financial Law 37 (2017): 205-265. Our emphasis on institutional evolution runs contrary to originalist theories that look to congressional intent to define supervision as solely concerned with national monetary policy (eg. Lev Menand, "Why Supervise Banks?: The Forgotten Past and Uncertain Future of a Distinctive Form of Governance," Vanderbilt Law Review [forthcoming]).
} 
Washington. With this information, supervisory authorities determined the prospects for the bank and advised its officers and directors toward better banking. ${ }^{15}$

Lending was the examiners' chief focus, and by the early twentieth century loan criticism was the primary tool for diagnosing and improving distressed banks. During their inspections, examiners sorted problematic loans into three categories-“slow," "doubtful," and "loss"-which represented a scale of illiquidity (slow) and poor credit quality (loss). A bank with too many slow loans was "frozen;" incapable of new lending and in danger if its deposit base dried up. A bank with too many losses was insolvent and promptly closed. ${ }^{16}$

Supervision through loan criticism provided each examiner with enormous, irreducible discretion. Loan assessments were fundamentally a matter of judgement and negotiation; they were never a simple accounting exercise. The Comptroller, Fed officials observed, "would not make a hard and fast rule as to what assets would be considered slow or doubtful."17

This discretion, however, was nearly impossible to use. Examination through criticism was an information regime, not an enforcement regime. Examiners could inform the bank that its loans were slow. The Comptroller could follow-up with a sternly worded letter. But unless the Comptroller wanted to invoke liquidation, a messy process likely to result in depositor losses and expensive litigation, the only power the Comptroller could exercise was harassment. Discretion, then, often took the form of forbearance. Supervisors could pester; they could not discipline (see sample examination reports in appendix)..$^{18}$

Fundamentally, bank examiners' only enforcement authority was to revoke a bank's charter, a punishment that, in practice, was often too destructive to use. Or, as one Comptroller phrased it, "there is no punishment but death." Bankers recognized this too. "Closing a bank is capital punishment for the bank," wrote former National City Bank of New York president Frank A. Vanderlip in 1932. "Every jury hesitates before pronouncing a death sentence," he continued, and "there is much the same hesitancy when considering a life or death sentence for a bank."

\footnotetext{
15 Annual Report of the Comptroller of the Currency (1930), 79-83; Annual Report of the Comptroller of the Currency (1922), 5; A. Barton Hepburn, Examination Books, 1889-1891, box 6, A. Barton Hepburn Collection, Columbia University; Paulger, "Policy and Procedure in Bank Examination," 219-227.

${ }_{16}$ Annual Report of the Comptroller of the Currency (1934), 3-4; Leo T. Crowley to Marriner S. Eccles, 9 Feb. 1938, Morgenthau Diaries, Book 120, 289, http://www.fdrlibrary.marist.edu/_resources/images/morg/mdo158.pdf; Walter A. Morton, "Liquidity and Solvency," The American Economic Review 29, No. 2 (June 1939): 279.

${ }_{17}$ Federal Reserve, Committee on Branch, Chain, and Group Banking, "225 Bank Suspensions: Case Histories from Examiners' Reports,” May 1933, 15, https://fraser.stlouisfed.org/title/797. The Federal Reserve lists this report as ca. 1932, but the final version was completed in 1933 (see Appendix).

18 Office of the Comptroller of the Currency, Department of Treasury, "Correspondence between Comptroller of Currency and First National Bank of Canton, Pa., May 9, 1904 to Oct. 16, 1918; on Government examinations and responses of bank, including data on excessive loans, losses on notes, and delinquent accounts for specific individuals and firms," 1 Jan. 1919, Proquest Accession no. https://congressional.proquest.com/congressional/docview/t66.d71.t12.2-16.1?accountid=13314; Annual Report of the Comptroller of the Currency (1931), 11-12.
} 
Criticism could provide a diagnosis, a prognosis, and possible therapy, but there was no political or technocratic will to invoke this irreversible treatment. ${ }^{19}$

Through the 1920s, examiners had no trouble identifying problem banks. In a 1932 Fed report focused on 225 failures between 1925-1930, examiners consistently criticized bank assets for years before the banks finally failed. "You left us in the situation of officiating at the birth of a bank, and at its death, but as a doctor in between with no power to make the patient take medicine," former Acting Comptroller Francis G. Awalt complained to Congress in $1934{ }^{20}$

The Federal Reserve Banks-the twelve quasi-private creatures of Congress designed to manage the nation's monetary and banking system-operated within a similar window of rules and discretion. The difference was that the Fed lacked much of a role as in chartering beyond accepting banks to the Federal Reserve System and therefore had no corresponding power of liquidation. The Reserve Banks undertook their most important supervisory work through their lending function. The Fed provided liquidity to the banking system by purchasing bank assets at a discount, offering banks a reliable source of cash in periods of market pressure. By law, the Reserve Banks could only rediscount what came to be known as "real bills," or liquid, commercial loans. The law said nothing, however, about credit quality. Because Reserve Banks assumed the credit risk of the loans they purchased, the Fed gradually developed "acceptability" requirements, in effect using rediscount policy to influence bank lending behavior. Like loan criticism, acceptability standards were fundamentally discretionary, rather than enforceable mandates, and they varied among the different Reserve Banks. ${ }^{21}$

Thus, to oversimplify, on the eve of the crisis the comptroller preferred liquidity (criticizing slow assets) but insisted on credit quality (closing insolvent banks); the Federal Reserve insisted on liquidity (only "real bills") and preferred credit quality (acceptability standards). The comptroller's main focus was bank solvency; the Federal Reserve's focus was its own solvency, and thus protecting the nation's reserves. As a result, the comptroller, responsible for burying dead banks but reluctant to do it, drifted toward forbearance. The Reserve Banks,

\footnotetext{
19 Annual Report of the Comptroller of the Currency (1915), 63; Frank A. Vanderlip, "What About the Banks," 5 Nov. 1932, Pamphlet Collection, Hagley Museum and Library, Wilmington, DE, 9.

${ }_{20}$ Committee on Branch, Chain, and Group Banking, "225 Bank Suspensions," 17; Stock Exchange Practices, Part 12, 73rd Cong. 5846 (1934) (Statement of Francis G. Awalt, Deputy Comptroller of the Currency).

${ }^{21}$ Ray B. Westerfield, "Marginal Collateral to Discounts at the Federal Reserve Banks," American Economic Review 22, no. 1 (March 1932): 42-43; Caroline Whitney, Experiments in Credit Control: The Federal Reserve System (New York, 1934), 41-42. For a good historical overview of the real bills doctrine and the Great Depression, see Judge Glock, "The 'Reifler-Keynes' Doctrine and Federal Reserve Policy in the Great Depression," History of Political Economy 51, no. 2 (2019): 297-327. For the influence of the doctrine, see Kathryn Judge, "The Federal Reserve: A Study in Soft Constraints," Law and Contemporary Problems 78 (2015), 64-96.
} 
aware of the comptrollers' authority to value banks assets, abetted this policy, because it kept banks open while keeping questionable assets off the Reserve Banks' balance sheets. ${ }^{22}$

Forbearance without legitimacy meant, however, that supervision was close to a dead letter. By the time the banking crisis arrived in force, supervisory credibility was in tatters.

\section{Keeping the Banks Open}

Federal supervisors honed the regime of criticism and forbearance during the 1920s, an era of turbulent economic growth and, under successive Republican administrations, government restraint. Yet, while presidents like Calvin Coolidge and Herbert Hoover were eager for private enterprise to take the lead, they nevertheless valued bureaucratic competence within the federal workforce. As such, the officials who would oversee the banking crises, particularly within the Comptroller's office, were experienced supervisors. John W. Pole, appointed Comptroller by Calvin Coolidge in 1928, began his career as an examiner in 1915 and rose through the office's ranks. Awalt, who became Acting Comptroller when Pole resigned in September 1932, served as a deputy and general counsel in the Comptroller's office beginning in 1922. Both had witnessed the long agricultural depression that steadily claimed undercapitalized rural banks, at the rate of 55 a month by 1929. Pole in particular attributed these failures to over-chartering and natural market transformations, and, on the eve of the crisis, was confident that the Federal Reserve would prevent any "general financial panics." 23

The failure of Tennessee's Caldwell \& Company in November 1930-a failure that sparked the first of the Depression's four banking panics-soon revealed the inadequacies of supervision through criticism. Founder Rogers C. Caldwell had built a shaky financial empire of insurance companies, industrial firms, and affiliate banks. After the 1929 stock market crash, Caldwell scrambled for cash. The National Bank of Kentucky, headed by speculator James B. Brown, agreed to step in. The deal fell apart, however, when an examiner reportedly revealed that the Kentucky bank had long been insolvent. Although possibly apocryphal, the story accurately reflected the Comptroller's assessment of the National Bank of Kentucky. For a decade, Brown had managed the bank, Comptroller John W. Pole later explained, in "utter disregard for the law and the regulations of the Comptroller's office."24

\footnotetext{
22 Emanuel A. Goldenweiser, American Monetary Policy (New York, 1951), 165.

23 Board of Governors of the Federal Reserve System, "John W. Pole,"

https://www.federalreservehistory.org/people/john w pole; Frances Gloyd Awalt, "Recollections of the Banking Crisis in 1933," Business History Review 43, no. 3 (Autumn 1969): 347; Annual Report of the Comptroller of the Currency (1929), 3-4.

24 John Berry McFerrin, Caldwell \& Company (Chapel Hill, 1939), 24-36, 127-128, 176; Elmus Wicker, The Banking Panics of the Great Depression (New York, 1996), 24-36; Operation of the National and Federal Reserve Banking Systems, Part 5, 71 Cong. 632 (1931) (Statement of J. W. Pole, Comptroller of the Currency).
} 
In 1925, after its affairs "took a change for the worse," a more senior examiner personally undertook the supervision of the Kentucky bank. Every six months, examiners combed through the books and demanded significant charge-offs and corrections for millions of loans that were slow and doubtful. None of this slowed Brown. He continued to expand the bank's balance sheet, eventually making the ill-fated decision to affiliate with Caldwell. By that time, Comptroller Pole concluded, "it was apparent to the examiners and to the comptroller that President Brown was not a safe banker." ${ }_{25}$

Unless examiners could demonstrate insolvency, however, and were willing to bear the consequences, they could only criticize. Perhaps by November 1930, one examiner had had enough. With the deal dead, contagion burned through Caldwell's affiliates and those of the Kentucky bank. Panic griped the middle South and Midwest. Hundreds of banks shut their doors. ${ }^{26}$

Without a viable enforcement mechanism, loan criticism could do little to change recalcitrant bankers' behavior, and, because examiners' assessments were private, there was no legal means for alerting the public to problem banks. Call reports theoretically advertised a bank's condition to the bank's creditors, but government assessments about the quality of these reports remained secret. In a system with discretion and little credibility, the public was willing to believe that the Bank of Kentucky had long been rotten, and that the examiners had been in on the secret. Runs, at the slightest provocation, became self-fulfilling, even inevitable.

As the crisis deepened in 1931, however, supervisory authorities extended discretion further as they sought to stem the spreading contagion and keep the banks from failing. They did so by incorporating bonds, with observable market prices, under the umbrella of supervisory judgement. Unlike loans, appraised through examiners' local knowledge and bargaining with bank managers, examiners could tally bond portfolios in minutes with the aid of a newspaper. As bond prices fell throughout 1931, however, bond depreciation threatened the solvency of scores of banks. Thus, the Comptroller and Fed gradually abandoned the prevailing practice of marking bonds to market and instead left examiners to assess each bond's "probable present and future real values." In essence, bonds became more like loans for supervisory purposes. To weather the crisis, the Comptroller issued a series of extraordinary telegrams, instructing national bank examiners to "exercise extraordinary discretion in their work and use every effort to encourage

\footnotetext{
${ }^{25}$ McFerrin, Caldwell \& Company, 129; Operation of the National and Federal Reserve Banking Systems, Part 5, 71 Cong. 632 (1931) (Statement of J. W. Pole, Comptroller of the Currency).

${ }^{26}$ Gary Richardson, "The Check Is in the Mail: Correspondent Clearing and the Banking Panics of the Great Depression," Journal of Economic History 67, no. 3 (September 2007): 659-661; Gary Richardson and William Troost, "Monetary Intervention Mitigated Banking Panics during the Great Depression: Quasi-Experimental Evidence from a Federal Reserve District Border, 1929-1933," Journal of Political Economy 117, no. 6 (December 2009): 1031-1073.
} 
and sustain the morale in banks examined." The word of the day was "leniency." "Present conditions," Pole instructed, "demand sympathetic treatment on the part of this office and examiners and can in an important measure tend to the alleviation of the difficult problems with which we are temporarily faced." 27

Demands for forbearance came from the top: President Hoover instructed the Comptroller "not to have any more bank failures." 28

In retrospect, President Hoover's and the Comptroller's effort to save banks by declaring assets worth what examiners said they were worth contextualizes other policy (in)actions, especially the Fed's failure to counteract the shrinking money supply. From a supervisory standpoint, expansionary monetary policy wasn't necessary to reflate the bond market, or for individual Reserve Banks to aggressively aid troubled banks in their districts. The Administration viewed examinations as the ultimate locus of authority over the valuation of bank assets. Banks were solvent because examiners declared them to be so. In December 1931, the Comptroller ordered examiners to "disregard market depreciation upon bonds not in default." When this memo came, New York Fed officials estimated that an astonishing 60 percent of New York banks, based on the market value of their securities portfolios, were impaired or insolvent. ${ }^{29}$

An open declaration that a near supermajority of banks were rotten was not conducive to a measured public response. Supervisors therefore didn't make that declaration, maintaining secrecy that likely made confidence more fragile as the crisis deepened. In this pre-deposit insurance era, depositors depended on examiners to do what depositors could not: inspect a bank's assets and verify its soundness. As public confidence waned, however, any perception of official censure or correction could go a long way toward closing a bank, harming the very depositors supervision was to protect. ${ }^{\circ}$

\footnotetext{
${ }^{27}$ Eugene Meyer to Francis G. Awalt, 13 Aug. 1931, quoted in Stock Exchange Practices, Part 12, 5832 (Statement of Francis G. Awalt); Telegram, James Pole to Chief National Bank Examiners, 6 Aug. 1931, quoted in Stock Exchange Practices, Part 12, 5835-6 (Statement of Francis G. Awalt).

${ }^{28}$ Stock Exchange Practices, Part 10, 73rd Cong. 4702, 4704 (1933) (Statement of Alfred P. Leyburn, Chief National Bank Examiner, Fourth Federal Reserve District).

29 Milton Friedman and Anna J. Schwartz, Monetary History of the United States, 1867-196o (Princeton, 1963), 312317; Allan H. Meltzer, A History of the Federal Reserve: Volume I, 1913-1951 (Chicago, 2003), 336-337, 412-413; Wicker, Banking Panics of the Great Depression, 85-86; Federal Reserve Board, "Meeting Minutes," 11 Aug. 1931 (11:30 AM), 7-8, https://fraser.stlouisfed.org/title/821\#31944; Eugene M. Lokey, "Along the Highways of Finance," New York Times, 20 Sept. 1931, N11; Walter Ferguson to F. G. Awalt, 9 Nov. 1931, folder 10, box 3, F. G. Awalt Papers, Herbert Hoover Presidential Library, Ames, IA (hereafter Awalt Papers); Memo, J. W. Pole to National Bank Examiners, 18 Dec. 1931, quoted in Stock Exchange Practices, Part 10, 4644 (Statement of Alfred P. Leyburn); "Banking Situation in the Second District," 8 Dec. 1931, folder 3, box 117, Eugene Meyer Papers, FRASER. This argument contrasts in particular with Friedman and Schwartz, who argue that "[b]y reducing the market value of the bond portfolios of banks, declines in bond prices in turn reduced the margin of capital as evaluated by bank examiners, and in this way contributed to subsequent bank failures (Monetary History, 312)."

${ }_{30}$ Memo, J. W. Pole to National Bank Examiners, 18 Dec. 1931, quoted in Stock Exchange Practices, Part 1o, 4644 (Statement of Alfred P. Leyburn); Douglas W. Diamond and Philip H. Dybvig, "Bank Runs, Deposit Insurance, and Liquidity," Journal of Political Economy 91, no. 3 (June 1983), 410.
} 
Secrecy extended to the banks being supervised. Examiners presented bank officers with a white examination report, reflecting their lenient evaluation of the bank, while simultaneously remitting a confidential yellow form to the Comptroller, revealing their actual assessment. Examiners worried that if given the full picture, bank directors would pull deposits from their own institutions ahead of the retail depositors they served. ${ }^{31}$

For the Hoover Administration-the bank supervisors very much included-the chief function of supervision remained keeping the banks open, not forcing them to close. The costs of the policy started to add up. Keeping unsound banks open undermined supervision's legitimacy. With the daily drumbeat of bank failures, examination ceased to be an engine of public confidence. Supervisors' somber declarations that banks were solvent could do little for banks' liquidity in the face of depositor withdrawals. Through 1931, scores of "solvent" banks continued to close as a consequence of bank runs. "We closed very few banks," Comptroller Pole explained defensively in March 1932. "Their depositors closed them." 32

On the eve of the collapse of the U.S. financial system, then, supervision could not carry the weight that Hoover had placed upon it. What was needed was a bold commitment of government action. Such a commitment, however, was antithetical to prevailing the theory of supervision, which emphasized guiding rather than directing private activity. Likewise Hoover's theory of governance. As the overall economy continued to decline into 1932, the fiction of solvency became harder to maintain. Supervisors could no longer secure the public's confidence. The bluff of paper solvency worked for a time, but when the collapse came, it exposed supervision as essentially impotent. 33

\section{Winter War, Spring Holiday}

Four days after Franklin Roosevelt defeated Hoover in the 1932 election, Acting Comptroller Francis G. Awalt painted Hoover's Treasury Secretary Ogden Mills a bleak picture of the nation's banking system. The carnage was plain to see. Local banking conditions were, district by district, "menacing and unstable," "unsatisfactory," "deplorable," and just plain "bad." Awalt ran out of adjectives. Major banks, systematically important to their local markets, were "frozen and dangerously extended," "either insolvent or have seriously impaired," and simply “embarrassed." Reflective of the Comptroller's policy "of not doing anything to rock the boat," these embarrassed banks all remained nominally open for business. Although Hoover would

\footnotetext{
${ }^{31}$ Stock Exchange Practices, Part 12, 5774-5775, 5845 (Statement of Alfred P. Leyburn; Statement of Francis G. Awalt). ${ }^{2}$ Richardson, "Categories and Causes," 606; Operation of the National and Federal Reserve Banking Systems, Part 2, 72nd Cong. 435 (1932) (Statement of J. W. Pole, Comptroller of the Currency).

33 Stock Exchange Practices, Part 10, 4646 (Statement of Alfred P. Leyburn).
} 
blame the coming wave of bank collapses on public distrust of Roosevelt, supervisory officials recognized a reckoning was imminent. Lenient supervision could not heal the banks; after Hoover's defeat, the administration's last shred of political legitimacy evaporated, too. The banking system, already deeply fragile, began to come apart. 34

The end began in Detroit. By the early 1930s, four-fifths of all deposits in the city were held by two enfeebled banking groups, the General Motors-backed Detroit Bankers Company and the Ford-affiliated Guardian Group. The Detroit Bankers Company's lead bank, the First National Bank of Detroit, "was not rotten," Chief Examiner Alfred Leyburn confided, "it was putrid.” It had been, going "back a considerable time." The Guardian Group, which Leyburn called "a promotion scheme," was not much better. Supervision through criticism had not guided Detroit's bankers to sound banking. Following a failed effort there to hold the city's crumbling banks together, Federal officials urged the governor, William A. Comstock, to declare a state holiday. After midnight on February 14, Comstock closed the state's banks. "I was at that time against a banking holiday in Michigan," Awalt recalled. "I felt sure it could not be localized and that it would spread to other states." He was right. Indiana, Maryland, Arkansas, and Ohio all declared by the end of February. March brought the avalanche. March 1, three states; March 2, 12 states; March 3, 9 states. The crash had come. 35

Many early states blamed Michigan, but by March 1933, the nation's banking system was overwhelmed by at least three converging crises. First, eroding public confidence intensified the ongoing solvency crisis which supervisors had been battling since 1930, a crisis punctuated by the closing of Michigan's banks in February. Later that month, attorney Fernand Pecora vividly exposed corrupt financial practices in the Stock Market Hearings, while Congress's publication of RFC recipients exposed these troubled banks to public scrutiny-and danger. Second, fears about bank solvency blended with corporate concerns that state holidays would freeze business assets, instigating a domestic shadow run. Local banks withdrew their deposits from New York correspondents to meet withdrawals of large corporate clients. The corporations, in turn, siphoned their cash directly to the New York banks. Finally, international financial turmoil and mounting uncertainty about Roosevelt's commitment to the gold standard led to heavy foreign

\footnotetext{
34 Francis G. Awalt to Ogden Mills, 12 Nov. 1932, folder 1, box 4; Francis G. Awalt, Memorandum for Files, 15 Nov. 1932, folder 10, box 3, Awalt Papers.

35 John T. Flynn, "Michigan Magic," Harper's Magazine 168 (Dec. 1932): 5; Darwyn H. Lumley, Breaking the Banks in the Motor City: The Auto Industry, the 1933 Detroit Banking Crisis and the Start of the New Deal (Jefferson, NC, 2009), 38; Stock Exchange Practices, Part 12, 5762 (Statement of Alfred P. Leyburn); Alfred Leyburn to the Comptroller of the Currency, 14 June 1932, quoted in Stock Exchange Practices, Part 10, 4638 (Statement of Alfred P. Leyburn); Awalt, "Recollections of the Banking Crisis," 349-356, 359-360; Kennedy, Banking Crisis, 77-95, 134; Rockoff, "The Meaning of Money in the Great Depression," 37; Charles W. Calomiris and Joseph R. Mason, "Fundamentals, Panics, and Bank Distress During the Great Depression," American Economic Review 93, no. 5 (Dec. 2003): 1615-1647; Wigmore, "Was the Bank Holiday of 1933 a Run on the Dollar," 739-756.
} 
withdrawals, particularly from the Federal Reserve banks. Pennsylvania Governor Gifford Pinchot, in Washington for the inauguration, was rousted in the early morning of March 4 "on a matter of utmost urgency" and hurriedly convinced to declare a state holiday, something just a few days before he had promised would never occur. Similar hastily-drawn orders came in Illinois and New York. There was, in short, a massive erosion of public confidence in the already fragile financial system, compounded in the days before inauguration by fears of devaluation. ${ }^{36}$

Yet despite the transparent need for action, Hoover refused to act. Administration officials considered instituting a national holiday beginning in the transition period, but no one wanted to take ownership of so disruptive a move. The statutory basis for such a strident intervention was the World War I-era Trading with the Enemy Act, which gave the executive substantial authority in a crisis but was politically risky. Hoover Treasury Secretary Ogden Mills felt that such an authorization "was not free from doubt" and that Hoover should not move forward "without the consent and approval" of the incoming Roosevelt Administration. William D. Mitchell, Hoover's Attorney General, agreed, calling the authority "a shoe string," even as others-such as RFC and Fed member Eugene Meyer-regarded the legal basis for such action to be amply justified. 37

The legal concerns may well have been a side show. Ultimately, Hoover wanted joint action with the incoming administration to handle a crisis that he regarded as a function of FDR's election, not any underlying instability in the U.S. banking system. Hoover was not indifferent to the swirling crisis; rather, he was a man of action determined to extract from the President-elect significant policy concessions. Roosevelt, however, refused to lend a cent of his electoral mandate to Hoover. Divided by egos, ideology, political sensibilities, and even a sense of the unfolding crisis, the two men refused to talk. Instead, discussions filtered from Hoover to his Treasury Secretary Ogden Mills, from Mills to incoming Treasury Secretary William Woodin in New York, from Woodin to Roosevelt in Washington, and back again. The standoff had real costs: "The procedure, incidentally, is not only ridiculous but criminal," Fed official Emanuel Goldenweiser noted at the time. "With the country on the verge of financial collapse, the inability of the incoming and outgoing administrations to talk to each other direct is utterly and totally unpardonable." 38

In his inaugural address, justifiably remembered for its towering rhetoric, Roosevelt confronted the crisis. "The money changers have fled from their high seats in the temple of our

${ }^{36}$ Kennedy, Banking Crisis, 131-135; Robert Lynn Fuller, "Phantom of Fear": The Banking Panic of 1933 (Jefferson, NC, 2012), 158-161; Arthur A. Ballantine, "When All the Banks Closed," Harvard Business Review 26, no. 2 (March 1948): 133-138; Schlesinger, Coming of the New Deal, 3; George W. Norris, Ended Episodes (Philadelphia, 1937), 220230.

37 Eric Rauchway, Winter War: Hoover, Roosevelt, and the First Clash Over the New Deal (New York, 2018), 205-209, 222; Emanuel A. Goldenweiser, contemporaneous notes, 3 Mar. 1933, folder 11, box 1, Awalt Papers.

${ }^{38}$ Kenneth Whyte, Hoover: An Extraordinary Life in Extraordinary Times (New York, 2017), 521-23; Schlesinger, Coming of the New Deal, 4; Goldenweiser, contemporaneous notes, 3 Mar. 1933. 
civilization," Roosevelt declared. "We may now restore that temple to the ancient truths." Behind these grand statements, Roosevelt offered little vision of the process, except that it would be a supervisory one. "There must be," the new president insisted, vaguely, "a strict supervision of all banking and credits and investments." The following day, with substantial help from holdovers from the Hoover Administration, the economic team presented Roosevelt with a plan to close the banks. What emerged was essentially the same as what the Fed presented Hoover the night before, the central component of which was a presidential declaration of a bank holiday using the 1917 Trading with the Enemy Act. This time, the president-Roosevelt, not Hoover-was ready to accept the advice and to act. 39

He wasted no time. "Say this Roosevelt is a fast worker," Comedian Will Rogers joked on the cover of the March 6, Los Angeles Times, the day the banking holiday took effect. "Even on Sunday, when all a President is supposed to do is put on a silk hat and have his picture taken coming out of church, why this President closed all the banks, and called Congress in extra session.” As Rogers' jest implied, the new Administration recognized that any durable solution to the crisis needed to rest on the full, undivided political authority of the federal government. In addition to closing banks, Roosevelt summoned Congress to special session on Thursday, March 9 to address the crisis. The shoe-string theory, even backed by a firm electoral mandate, was not enough to legitimize the holiday. The Administration needed substance, not mere talk. ${ }^{40}$

\section{The Work of the Holiday}

Together, Hoover's beleaguered staff and Roosevelt's team recognized that the holiday afforded them one-and only one-opportunity to rescue the banking system. Roosevelt's Proclamation 2039 prohibited "all banking transactions," requiring "no such banking institution or branch [to] pay out, export, earmark, or permit the withdrawal or transfer in any manner ... of any gold or silver coin or bullion or currency." The holiday thus simultaneously permitted some breathing room on the question of dollar devaluation, while giving supervisors the space to address the solvency crisis first. Success, Ogden Mills explained to William Woodin on March 4, "would depend on the frankest disclosure to the public of existing conditions and an unyielding determination to resist all pressure to deal with individual banks on any other basis than reality." Certainly, easy advice to give on the way out the door. However, Mills' injunction revealed the necessity, as he understood it, of mobilizing the vast accumulation of supervisory knowledge.

39 Franklin D. Roosevelt, "Inaugural Address," 4 Mar. 1933, American Presidency Project, https://www.presidency.ucsb.edu/documents/inaugural-address-8.

40 Will Rogers, "Will Rogers Remarks," Lost Angeles Times, 6 Mar. 1933, 1; Franklyn Waltman, Jr., "Roosevelt Proclaims National Bank Holiday to Last Until Friday,” Baltimore Sun, 6 Mar. 1933, 1. 
Frank decisions had to be made on the basis of reality, and government's capacity to apprehend that reality relied on the supervisory system. Some banks, Mills explained, were "hopelessly insolvent and incapable under any circumstances of reopening." As powerful as Roosevelt's inaugural rhetoric had been, it could not do better than Hoover's insistence that the banks also stop failing. The new administration could only save the banking system by determining which banks fell into this category and keeping them closed..$^{11}$

Hoover's staff, hardened by years of frantic struggle, was prepared for this moment, so that even while Roosevelt's team was clearly in charge, it was the previous administration's plan that went into motion. "Two main questions confronted us" on inauguration day, Awalt recalled: "(1) what banks could be opened quickly in order that the country might function; (2) how to keep them open." The federal officials "had no positive knowledge of the condition of the state banks," but through the biannual examinations, could estimate that perhaps 2,200 out of 5,938 national banks "could be reopened at once and meet all demands on them." To facilitate the reopening, Hoover's staff developed a classification system, labeling these liquid banks "Class A." They also "knew some would not open at all," and these cases-“doomed to failure"-they designated Class C. Drawing the lines between these categories and then working out a means of opening as many Class B banks as quickly as possible, would, they believed, comprise the essential work of the holiday. $4^{2}$

By Tuesday, March 7, Woodin fully committed to the Hoover team's plan. In doing so, he wed the legitimacy of the new administration to the supervisory apparatus, backstopping the financial system with political capital. The first test of this strategy came before Congress. The administration needed to show that there were enough Class A banks to serve the basic needs of the country, and to convince Congress to provide new supervisory tools to reorganize and reopen class B banks. On March 8, Woodin asked the Comptroller of the Currency and each Federal Reserve Bank to "prepare as soon as possible tomorrow a list of member banks...which you regard to be solvent as going institutions on fair appraisals not on liquidating basis." As these instructions made clear, the administration intended supervisors to maintain the posture of forbearance, estimating which banks, under normal- “fair"-market conditions, would be safe and solvent. The implication was intentional: current market conditions were decidedly unfair. Using their files, the twelve Chief National Bank Examiners sent telegrams through the day on March 8, 1933, providing Awalt with additional banks that could be reopened. Awalt's staff marked the banks

\footnotetext{
${ }^{41}$ Franklin D. Roosevelt, "Proclamation 2039--Declaring Bank Holiday," 6 Mar. 1933, American Presidency Project, https://www.presidency.ucsb.edu/documents/proclamation-2039-declaring-bank-holiday; Ogden Mills to William Woodin, 4 Mar. 1933, folder 7, box 1, Awalt Papers.

${ }^{42}$ Francis G. Awalt, ["Personal Account of F. G. Awalt"], Mar. 1933; Emanuel Goldenweiser, contemporaneous notes, 3 Mar. 1933, folder 11; Ogden Mills to William Woodin, 4 Mar. 1933, folder 7, box 1, Awalt Papers.
} 
with pins on a map. "The President," Awalt recalled, "thought it great." Nevertheless, "while the banks showed a fair geographical distribution, it was obvious that the country would still be paralyzed unless we could open more banks." 43

The Reserve Banks were more cautious, fearful of being held responsible for keeping troubled banks open. On March 9, Assistant Treasury Secretary James Douglas informed the Board that, "the lists received, have been found not to meet the requirements of the Secretary of the Treasury." He demanded revisions that followed Awalt's liberal classifications. Board members worried that if they allowed questionable banks to open, they would be called on to support these institutions unconditionally, exposing the Reserve Banks to "heavy losses." As Awalt recalled, "both Harrison and Morrill were zealously attempting to protect Eugene Meyer, and the Federal Reserve System,"-perennial targets of the now retired Hoover-“from any embarrassment or future criticism."44

To reassure the Board, Roosevelt promised to persuade Congress to cover their losses and urged them to assess liberally the bank balance sheets they reviewed when lending to banks in distress. "There is a very definite obligation on the Federal Government," Roosevelt assured the Board, "to reimburse the 12 Regional Federal Reserve Banks for losses which they may make on loans under these emergency powers." In this pivotal moment, the Administration added financial capital to its political capital and made the process of supervision one guaranteed by the federal government. 45

As administration officials worked to convince the Fed to commit, the Emergency Banking Act rocketed through Congress, where few legislators who voted on the bill had the pleasure of reading it. Drafted by Fed officials and Hoover administration staff, the law retroactively authorized the holiday. Further, following "a draft...which [Awalt] had under lock and key in [his] office," it created "conservatorship," a new supervisory tool which enabled the comptroller to take possession of a bank, with the aim of ultimately reopening it rather than winding it down. Insolvency would no longer be a death sentence; supervisors could act forcefully to repair troubled banks while also bolstering confidence that the banks that remained open were sound. Carter Glass, who ushered the bill through the Senate, relied on Awalt's estimate that the administration could eventually open 5,300 national banks with the legislation and 2,600 without. As Glass

\footnotetext{
43 Kennedy, Banking Crisis, 168-174; Marcus Nadler and Jules I. Bogen, The Banking Crisis: The End of an Epoch (New York, 1933), 162-165; Federal Reserve Board, "Meeting Minutes," 8 Mar 1933, 3, https://fraser.stlouisfed.org/title/821\#31067; Awalt, "Recollections of the Banking Crisis," 366; Awalt, ["Personal Account of F. G. Awalt"].

44 Federal Reserve Board, "Meeting Minutes," 9 Mar 1933, 7, https://fraser.stlouisfed.org/title/821\#28.365; Awalt, "Recollections of the Banking Crisis," 368n5; Kennedy, Banking Crisis, 183-184.

45 Federal Reserve Board, "Meeting Minutes," 11 Mar. 1933, 3-4, https://fraser.stlouisfed.org/title/821\#31477.
} 
assured his fellow Senators, "only those banks which are literally rotten, and which ought to have been permitted to fail long ago, will not be allowed to open."46

Congress was, the Senators recognized, about to provide supervisors with new authority to act decisively, not to keep banks open, but to close them, some temporarily, others permanently. For Michigan Senator Arthur Vandenberg, this represented a shocking expansion of federal power. "The Comptroller," Vandenberg objected, "is about to decide tonight what banks in America are solvent and what banks in America are not solvent." But the Republican also conceded that "the new administration is fresh from a popular mandate" and "is entitled to an unhampered chance to save the crisis." That evening, Roosevelt signed the law and extended the holiday indefinitely, buying the supervisors time to make those judgements and deliver on the vision of a political and technocratic approach to the crisis's resolution. ${ }^{47}$

On March 10, Roosevelt issued an order establishing the procedure for reopening the banks. National and state-chartered banks that were Fed members would submit applications to their local Federal Reserve Bank. The Reserve Banks, in consultation with the Chief Examiners from the Comptroller's office, would then evaluate each application. A national bank essentially needed three independent approvals, from the examiners in the field, from the local Federal Reserve Bank, and from the Comptroller's office in Washington. The Secretary of the Treasury, upon whose authority they would open, Awalt explained to the Federal Reserve Board, "would not be able to take up each case individually." For state banks outside the Fed system, reopening decisions lay with the state banking authorities, a calculated gamble which relied on state supervisors' incentives to maintain the legitimacy of state-level governance vis-à-vis their federal counterparts. Banks in Federal Reserve cities, Roosevelt told the press, would open on Monday, March 13. Banks in cities with clearinghouses on March 14, and all other banks on March $15 .{ }^{48}$

The supervisors had the weekend to determine, as best they could, which banks should open immediately and which should not. Eichengreen's skepticism, quoted at the article's outset, assumed that the sorting process began on that day, but it hadn't: the genius of the holiday was to mobilize and transform the supervisory information regime, giving supervisors the authority to act upon the judgements they had been making all along.

It was not an orderly transformation. Each Reserve Bank devolved into chaos as examiners combed through old examination reports, searching for a plausible if generous basis to permit the

\footnotetext{
${ }^{46}$ Kennedy, Banking Crisis, 175; Awalt, ["Personal Account of F. G. Awalt”]; 77 Cong. Rec. 58 (1933) (Statement of Sen. Glass).

4777 Cong. Rec. 62 (1933) (Statement of Sen. Vandenberg); Kennedy, Banking Crisis, 176-177.

48 Franklin D. Roosevelt, "Executive Order 6073-Reopening Banks," American Presidency Project, https://www.presidency.ucsb.edu/documents/executive-order-6073-reopening-banks; J. F. T. O'Connor, The Banking Crisis and Recovery Under the Roosevelt Administration (Chicago, 1938), 19; Federal Reserve Board, “Meeting Minutes," 11 Mar. 1933, 15, https://fraser.stlouisfed.org/title/821\#31477.
} 
banks to reopen. At the New York Fed, the Board convened every day from 10 am to $6 \mathrm{pm}$. As examiners analyzed examination reports, they passed the files up to senior officers, who in turn made the case for each bank to the board. Meanwhile, distraught bankers milled around the lobby. "Money had fled from small towns to New York, therefore New York might have money," J. Herbert Case a long-time New York Fed employee recalled. In what Case called a "keep your shirt on" operation, the former president of the New York State Bankers Association spent the holiday reassuring these worried men. The Richmond Fed was similarly packed. "The auditorium is full," Governor George Seay described, "the directors' room has been full, our discount room is full, and the lobby is pretty well occupied, and most of the desks have bankers conferring-we are trying our best to avoid physical breakdown of the officers." 49

The stress was intense, the pace unrelenting. "Sleep was practically unknown to many of us," Awalt recalled. "My usual routine was to arrive home in the morning, around seven, get a hot toddy, prepared by Mrs. Awalt, sleep for at least an hour, have a shower and return to the Treasury." According to reporter Ernest K. Lindsey, "the main participants in the drama were too numerous and they emerged from long days and nights of tension with blurred and conflicting memories." The task was "so onerous and responsible, and performed under such a cruel limitation of time," that the head examiner at the Philadelphia Fed suffered a breakdown that "compelled him to rest for a year before his health was completely restored." 50

\section{Only Sound Banks}

Meanwhile, preparations were made for Roosevelt to do something new: address the nation by radio in a frank, candid, reassuring tone to explain the banking crisis and what would happen next. As New York Governor, Roosevelt had made a name for himself in broadcasting, "taking the issues to the people." The stakes for what would become the first "fireside chat" were much higher in March 1933 than they had ever been in Albany. As the draft circulated among those working tirelessly on the examination process, the president's promise that only "sound banks" would open, caused the banking staff intense apprehension. "In our hurry to complete the program," Awalt told the President, "there might be some exceptions." Roosevelt, though, understood the gamble and understood that he had to restore unerring confidence. "He stated in

\footnotetext{
49 Committee on the History of the Federal Reserve System, "Interviews with Mr. J. Herbert Case," 26 Feb. 1954, Folder 1, Box 2, Committee on the History of the Federal Reserve System, https://fraser.stlouisfed.org/archival/1342/item/458291; George Seay to David R. Coker, quoted in Fuller, "Phantom of Fear," 198.

$5^{\circ}$ Awalt, "Recollections of the Banking Crisis," 369n6; Ernest K. Lindsey, quoted in Kennedy, Banking Crisis, 237; Norris, Ended Episodes, 232-233.
} 
no uncertain terms that that was what we were going to do, 'open only sound banks." Awalt recalled. "I had nothing more to say." ${ }_{1}$

The gamble illustrated just how much the political and the technical combined to create the legitimate. Roosevelt, even with his electoral mandate and his larger-than-life persona, could not simply will away the financial and economic crisis. He needed what only the bank examiners could offer: the assurance that the banks that opened were indeed "sound" on some defensible criteria. In their hurry, examiners would-and did-make mistakes, but the credibility of the enterprise required an unshakable public commitment to supervisory expertise. $5^{2}$

The legitimacy of the moment depended on both forces-the political and technical-to work in harmony. This is clear from the speech itself, in which Roosevelt founded his government's commitment to preventing "another epidemic of bank failures" on the work of federal supervisors. "We start tomorrow," Roosevelt explained, "with the opening of banks in the twelve Federal Reserve Bank cities -- those banks which on first examination by the Treasury have already been found to be all right." He continued, "On Wednesday and succeeding days banks in smaller places all through the country will resume business, subject, of course, to the Government's physical ability to complete its survey. It is necessary that the reopening of banks be extended over a period in order to permit the banks to make applications for necessary loans, to obtain currency needed to meet their requirements and to enable the Government to make common sense checkups." The stamp of approval by examiners assuring the solvency of individual banks failed again and again in the slow-burning crises beginning in the late 1920s. The holiday's success required FDR's charisma and the examiners' expertise. Roosevelt invited his listeners to imagine examination, physical surveys, and common-sense checkups, because the flurry of supervisory activity that enabled the banks to open was largely hidden from public view. 53

The results, however, spoke boldly. When the licensed banks opened in Federal Reserve cities on Monday, March 13, Americans expressed their confidence in the administration through a flood of cash and gold deposits. "The people," Woodin remarked, "have responded." In many communities, bank reopening brought more than financial stability. When Philadelphia's only African American owned bank was licensed to reopen on March 13th, it was, according to the Philadelphia Tribune, "epoch making." Depositors were "electrified with racial pride." After the first three days, about half of all banks, representing 90 percent of deposits, had opened. "The

\footnotetext{
${ }^{51}$ Grace Tully, FDR: My Boss (New York, 1949), 88, quoted in Geoffrey Storm, "FDR and WGY: The Origins of the Fireside Chats," New York History 88, no. 2 (Spring 2007): 178; Amos Kiewe, FDR's First Fireside Chat: Public Confidence and the Banking Crisis (College Station, TX, 2007), 76-82; Awalt, "“Recollections of the Banking Crisis," 370 .

52 Eugene M. Stephens to Eugene R. Black, 2 June 1933, folder 2, box 2165, Records of the Federal Reserve System, https://fraser.stlouisfed.org/archival/1344/item/469284.

53 Roosevelt, "Fireside Chat on Banking."
} 
reopening of the banks restored in the mind of the public confidence in the banking structure," the Federal Reserve Bank of Boston concluded.54

Just as the declaration of banking holidays-state and federal-involved the destructive convergence of banking and currency panics, so too did reopening involve the redemptive convergence of new banking and currency policies. Under the authority of the Trading with the Enemy Act, Roosevelt stabilized the currency by criminalizing gold hoarding. Even before the holiday concluded, hoarders clamored to return bullion to the banks. Most, though, deposited their stashes rather than exchanging them for paper currency, a trend which continued after formal reopening. A day after the holiday ended, one Chicago bank reported opening 2,500 to 3,000 new savings accounts, explaining: "In many cases these people frankly said they has been hoarding but that their confidence had been restored and they wanted to get their cash back into bank accounts." By the end of March, \$1,250 million in currency, 17 percent of that in circulation, had been deposited-deposits that helped further stabilize the shakiest of the sound banks. For its first few weeks, the success of the New Deal was measured in such deposits. 55

Capitalism had been saved, but many of the capitalists were not. When the holiday concluded on March 15, only 75 percent of national and federal reserve member banks had reopened, leaving 1,400 national banks and $221 \mathrm{Fed}$ member banks in the hands of federal conservators or similar state-level officials. Some reopened later, others only after reorganization, some never again. Nearly 15 percent of national and federal reserve member banks closed permanently after the holiday. The picture was similar for state-chartered, non-member banks. About 3,000, or 30 percent, remained unlicensed by mid-April 1933, 1,173 of which would suspend permanently. The administration sought to make clear that banks which did eventually open were just as sound as those which had opened immediately. In his fireside chat, Roosevelt said "A bank that opens on one of the subsequent days is in exactly the same status as the bank that opens tomorrow." Behind the scenes, however, officials urged caution. "It seems to me fundamental," Awalt wrote, "that we should be very rigid, both in examination and requirements, from now on in order to keep these banks sound." Roosevelt had promised to only open sound banks; bank supervisors kept it by keeping unsound banks closed..$^{6}$

\footnotetext{
54 "City Recovers Confidence as 34 banks reopen," Chicago Tribune, 14 Mar. 1933; S. A. Hayes, "Local Bank Rides Financial Storm," Philadelphia Tribune, 16 Mar. 1933; Kennedy, Banking Crisis, 187; "Bank Openings by States," New York Times, 17 Mar. 1933, 4; Federal Reserve Bank of Boston, Nineteenth Annual Report of the Federal Reserve Bank of Boston (1933), 7.

55 "Hoarders of Gold Will be Identified," Washington Post, 9 Mar. 1933, 1; "Hoarders in Fright Turn in \$30,ooo,ooo," New York Times, 10 Mar. 1933, 1; “Gold Inflow Brings in \$20,000,000 in Day,” New York Times, 11 Mar. 1933, 1; "Confidence Increasing as More Banks Reopen," Wall Street Journal, 15 Mar. 1933, 10; Federal Reserve System, Annual Report of the Federal Reserve System (1933), 14.

${ }^{56}$ Annual Report of the Federal Reserve System (1933), 22; Annual Report of the Federal Reserve System (1935), 176; Kennedy, Banking Crisis, 188-189 (Awalt quote, 189); Roosevelt, "Fireside Chat on Banking."
} 
In this way, the holiday transformed supervision into a decisive institution of federal power, which, in the years ahead, would enforce the government's guarantee that open banks were sound. In 1933 and 1934, supervisors used their new authority to manage the transition from Roosevelt's implicit guarantee to formal federal deposit insurance, in particular by compelling many bankers to accept RFC recapitalizations as a condition of FDIC membership. Emboldened examiners were occasionally too stringent, and even Roosevelt urged them to ease up. Nevertheless, the legitimate exercise of supervisory judgement remained central to federal financial governance well beyond the New Deal. Empowered supervisors stood behind postwar financial stability. In the 1960s and 1970s, Congress expanded the supervisory responsibilities, to include consumer protection, anti-discrimination, and anti-money laundering. Only during the 1980s, when desupervision accompanied deregulation and the larger delegitimating of the New Deal state, did policymakers undermine the regime of supervisory judgement. 57

\section{Conclusion}

Promising the nation that "only sound banks" would open, Roosevelt created a guarantee with various components. It was a reputational guarantee as he tied his political mandate to the results of this holiday. It was a financial commitment, as in the example of guaranteeing the liabilities of the Reserve Banks. It was also a guarantee made possible by an army of federal supervisors relying on years of critical expertise that had laid fallow. This stood in stark distinction to Hoover's policy of refusing to close banks, which amounted to an endorsement of all the banks and ultimately an endorsement of none of them. Hoover pushed supervisory forbearance to-and beyond-its functional limits in his effort to keep the banks open. Roosevelt and his team (including holdovers from Hoover) had a different insight: recovery required legitimacy, and legitimacy needed failure.

In this way, the bank holiday of 1933 reconstituted and expanded the legitimacy of the supervisory apparatus. In the process, the purpose and modality of supervision changed. Before the crisis, "the unadvertised but chief function of" supervision was to keep "banks from failing." During the crisis, supervisors "did not close banks." Yet it was precisely failure-and the supervisors capacity to declare failure-that was vital to creating this legitimacy, even if the actual decision-making process was hurried and imperfect. Closing the banks, and keeping some banks

57 Jesse H. Jones, Fifty Billion Dollars: My Thirteen Years with the RFC, 1932-1945 (New York: 1951), 26; Schlesinger, Coming of the New Deal, 428-430; Annual Report of the Federal Deposit Insurance Corporation (1934), 14-16; "Expansionists at Hyde Park," Wall Street Journal, 10 Sept. 1934, 1; "Roosevelt Backs Charges Examiners Balk Good Loans," Wall Street Journal, 13 Sept. 1934, 1; Stuart L. Weiss, The President's Man: Leo Crowley and Franklin Roosevelt in Peace and War (Carbondale, Il, 1996), 42. We examine desupervision in our forthcoming history of federal bank supervision (Peter Conti-Brown and Sean H. Vanatta, The Banker's Thumb: A History of Bank Supervision in America [Cambridge, MA, forthcoming]). 
closed, changed the rules of the game. It enabled supervision to begin a halting transition from associational governance, seeking to guide bank behavior, to a decisive bureaucratic power. The bank holiday worked, in the last analysis, not by opening banks, but by keeping them closed. $5^{8}$

This transformation, moreover, operated in conjunction with Roosevelt's decisive and necessary devaluation of the dollar. Under Roosevelt, the supervisory regime shifted from showing strength by not closing banks to showing judgement by closing banks where necessary. Likewise, the administration shifted from showing strength by staying tied to gold to showing judgment by revaluing where necessary. Gold's nadir was supervision's apotheosis: supervisory discretion became the force behind the dollar.

This account of federal supervisors' failed and then successful efforts to save the banking system corrects existing scholarship on the Depression's banking crises in important ways. Much of that focus has been on the role of too-tight monetary policy-whether in service of international commitments or outmoded ideas about collateral quality-in exacerbating the Depression. We argue that the focus on mechanisms (monetary and credit policy) misses the important role of the mechanics (the bank supervisors), both when they failed and when they succeeded. In other words, an account of the descent into the Depression and the rise of the New Deal which skips the essential role of bank supervision misses a key part of that important narrative. 59

This article also challenges prevailing accounts of Roosevelt's transition to power and explanations for the success of the 1933 Banking Holiday. These events did not rely solely on Roosevelt's electric charisma, however essential that charisma was, contemporaneously and to historians. Nor did these events rely solely on the implied guarantee that the federal government stood behind any open bank, though these guarantees were important, too. Instead, the information, expertise, and life-and-death judgement mobilized by bank supervisors before and during the holiday gave credibility to Roosevelt's soaring oratory. Supervisors secured the necessary political legitimacy from the new administration and provided, in turn, the necessary technical legitimacy that Rooseveltian assurances were based on more than hope-against-fearitself rhetoric.

To be clear, in the months and years after 1933, supervisory legitimacy remained tenuous. The solidification of this legitimacy, the multiplication of supervisory functions, and the expansion of supervisory authority during the New Deal and after all remain topics ripe for scholarly investigation. Indeed, supervision as a distinct mode of governmental power-"the

\footnotetext{
$5^{8}$ Thomas J. Sargent, Rational Expectations and Inflation (New York, 1986).

59 The rise of supervision only continued through the advent of the Federal Deposit Insurance Corporation, a kind of institutionalization of the holiday ethos that fundamentally altered the practice of supervision. Federal Deposit Insurance Corporation, The First Fifty Years: A History of the FDIC, 1933-1983 (Washington DC, 1984).
} 
process," according to Federal Reserve Vice Chairman for Supervision Randy Quarles, "through which our policy objectives are given effect"-demands much greater scholarly attention, not only from historians, but from banking scholars, lawyers, and economists. ${ }^{60}$

Historical accounts of supervision through crisis, like this one, are essential elements of this larger project, and the fact that a reinterpretation of the Depression and bank holiday through a supervisory lens opens up so many more questions is a strength of the effort. Not only do historical accounts shed light on the past development of supervision as a unique modality of governmental power, but they also provide lessons for policymakers likely to confront crisis in the future. This history of the 1933 Banking Holiday, to draw one contemporary parallel, suggests that the 2009 Supervisory Capital Assessment Program, the so-called stress-tests, succeeded, in large measure, by declaring that 10 of the 19 largest U.S. banks had failed. Declaring failure enabled supervisory officials to demand significant recapitalization, aiding long term recovery and reestablishing supervisory legitimacy. By contrast, recent efforts to weaken the stress test regime suggest the possible return to a posture of forbearance, one that might keep banks open-and make it harder, when necessary, to close them. ${ }^{61}$

\footnotetext{
6о Randal K. Quarles, "Spontaneity and Order: Transparency, Accountability, and Fairness in Bank Supervision,” 17 Jan. 2020, https://www.federalreserve.gov/newsevents/speech/quarles20200117a.htm (accessed, 8 Aug. 2020). Importantly, Quarles has also issued a plea for more scholarly attention on supervision as a field of study. Randal K. Quarles, "Law and Macroeconomics: The Global Evolution of Macroprudential Regulation," September 27, 2019, https://www.federalreserve.gov/newsevents/speech/quarles20190927a.htm (accessed, 8 Aug. 2020).

${ }_{61}$ This is also Ben Bernanke's view, who describes the mechanics of the SCAP in detail. See Ben Bernanke, The Courage to Act: A Memoir of a Crisis and Its Aftermath (New York, 2016), 394-98.
} 


\section{Appendix}

This appendix contains the anonymized case history of a failed national bank (possibly the First National Bank of Abbeville, Alabama), one of six of which accompanied the Federal Reserve Committee on Branch, Group, and Chain Banking's report, "225 Bank Suspensions: Case Histories from Examiners' Reports." The committee completed the report in late 1932, revised it, along with several others it produced, in the months after the 1933 bank holiday, and submitted it Congressional leaders crafting the Banking Act of 933. Fed officials used examples like the one reproduced here to show why examiners needed authority to force change in troubled banks, rather than merely bringing problems to bank directors' attention and suggesting corrections. ${ }^{62}$

The case consists of examination report excerpts, from 1920 until the bank's failure in late 1924. The excerpts showcase the process of federal bank examination as it was practiced in the runup to the banking crisis, particularly the use of loan categorization to identify troubled banks and to advise managers on how to repair their institutions (note the "slow", "doubtful", and "losses" columns in the upper right corner and use of the terms throughout). Over the years covered, the bank suffered from poor management, declining deposits, declining loans, and a high proportion of criticized assets. In September 1923, examiner "B" sought to bring "the bank's condition squarely before" the bank's board. In April 1924, however, examiner " $\mathrm{C}$ " found "no improvement in the condition or management since the last examination," and the bank soon closed.

"Bank examination," Comptroller Henry Dawes wrote in 1923, "involves very much more than a mere scrutiny of figures. Questions of moral character, of local reputation, of valuations of securities, of conformity to laws and rulings-these and many other elements enter into a proper examination." Those social, cultural, and legal aspects of examination are present in the excerpts as well, particularly through the casual racism in the early excerpts. Indeed, in addition to what they reveal about business and supervisory practices, examiner reports can be useful for scholars seeking to answer a range of research questions, especially given the centrality of banks to the economic and social lives of their communities. ${ }^{63}$

\footnotetext{
${ }^{62}$ Committee on Branch, Chain, and Group Banking, "225 Bank Suspensions," 254-257; Annual Report of the Comptroller of the Currency (1925), 237; Board of Governors of the Federal Reserve System, Committee on Branch, Group, and Chain Banking, Summary of Reports Prepared for the Information of the Federal Reserve System, 1933, https://fraser.stlouisfed.org/title/813; Carter Glass to Eugene Meyer, 15 April 1933; E. A. Goldenweiser to L. R Rounds, 27 April, 1933; E. A. Goldenweiser to Carter Glass, 25 May 1933, Committee on Branch, Group \& Chain Banking (1933-1954): Branch Banks, folder 4, box 1797, Records of the Federal Reserve System, Record Group 82, https://fraser.stlouisfed.org/archival/1344/item/593326.

63 Annual Report of the Comptroller of the Currency (1923), 9. The National Archives hold examination reports in several collections, most notably the Comptroller of the Currency (Record Group 101, bulk of reports span 1863-1917) and the Federal Deposit Insurance Corporation (Record Group 34, examination summaries for 1934-1970).
} 
Case 6

Eank Organized: 1901

Populatiori of town:

1200 ( 1910 Consose)

Bank Suspended: 1924

1300 ( 1920 Co.J903).

2000 ( 1930 Census)

Principel Grops or Induatry Served by Bank:

Cotton and corn.

Important Brcerpts from Reports of Inraminat1on: (Amounts 1n thousands of dollars)

\begin{tabular}{|c|c|c|c|c|c|c|c|c|}
\hline Date & Cep. & $\begin{array}{l}\text { Surplug } \\
\text { E Profito }\end{array}$ & Ioeng & Depoe1ts & $\begin{array}{l}\text { Borrol- } \\
\text { 1ngs } \\
\end{array}$ & \multicolumn{3}{|c|}{$\begin{array}{l}\text { Classified Assets } \\
\text { slor Doubtful togags }\end{array}$} \\
\hline 7-20 झram. H: & 100 & 103 & 479 & 356 & 87 & 13 & 1 & 1 \\
\hline 11-26-20 Bram. H: & 100 & 106 & 474 & 332 & 143 & 10 & 10 & \\
\hline
\end{tabular}

4-7-2l Exam. B: "The management of th1s bank is left entirely with the Ceshler Mr. A. He 1s apperently an easy going sort of fellow, anxious to make money and in his eagerness to make money 1 t eppears that he loses olght of the principal to a great extent and can see only the 1nterest or discount recelved. \& large anount of the loans are to negro farmors. The negro as a rule lo poor pay and does not try to accumalate money and get ahead. Three re groes have borrowed from the bank a total of $\$ 23,192.57$ of which amount $\$ 3,000$. 1s admitted as being doubtful. There are many other notes of negroes but are for small amounts and in event of losses on th1s class of paper tho eggregate not look favorably upon the contents of the note case as a whole for the lines of credit extended are in my fudgment too large in view of the security furnl shed and it will take some time to work out. A great deal depends on the crops this year and the prices received in the fall. The bank has $\$ 1,610.69$ surplus and undivided profits and there 1s no immediate danger. The maln crop is cotton which is being held up dine to low prices offered for eame, however there seems to be elight improvement in the market, and the enticipated marketing of same within the next few meeks will materially relieve the etrained situation,"

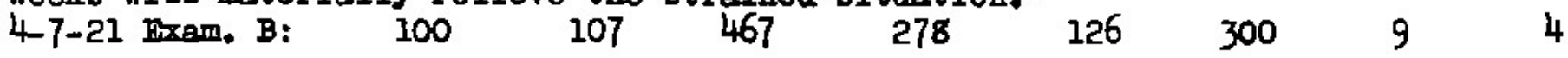

5-18-21 knam. B: "An examination of this bank was made in compliance with your office letter of May 12, due to the expiration of the1r charter on Aug. 16, 1921. When the following matters heve been corrected, I recommend that their charter be extended. The line to the $X$ Co., of $\$ 115,866.35$ is peid or very groatly reducod. A aays that the ent1re line will bo paid by Aug. 1, 1921 and charter does not oxpiro until Aug. 16, 1921. The doubtful and loss paper lo completely charged off."

5-18-21 Fram. B: $100 \quad 101 \quad 450 \quad 244 \quad 151 \quad 74 \quad 34 \quad 2$

4-11-22 Exam. B: "The large amount of elow paper is due to the lending of too anuch money to the farmers curing the period of inflation. It appears that it will take soveral years to liquidate paper in general. It is to be noted that many loans are made to negroes in large amount. The Southern negro is as a rule very poor pey. One line in perticular is that of $B$ a negro texent. This negro ores the bank $\$ 5.949 .37$ and his landlord owes the bank $\$ 14,673.30$. Then Geshier $A$ was questioned regarding these notes, he stated thet they wero perfectly good 


\section{Case 6 (Contimud)}

Surplus

Date

Cep. \& Profit
Borrow-

Claspified Assets

Inse Slor Doubtful Iosses

and that $\mathrm{B}$ wa helping his landlord pay off his mortgege on the farm, and I aaked A what pert of the ferm the negro got won the mortgage wes peid and ho beid 'None.' The above to related in order that you may better underatand the aitustion and ses it as it $1 \mathrm{s.} "$

4-11-22 Bram, B: 100

$88 \quad 376 \quad 256$

125

231

10

0

9-22-22 Eram. B: "It is to be noted from this report that a very unsetiafactory condition exiets. From the manner in which the accounts vero kept, I became very ouspicious as to the gemineness of the various transections and accordingly proceoded very carefully. Thile I was experiencing coneiderablo difficulty in balancing the notes, m assistant ras having similnr experience with the bank's dotails. Cashier A is to blams for the condition that exists, and elso the Boerd, to a certain extent. An earnest effort was made to imprees upon the Board that they had certain duties to perform, wintch could not be delegated to somsone else. At a directors' meeting on Sept. 20th, the board voted to decrease aurplus account $\$ 25,000$ and credit undivided profita itth a like amount. It $1 \mathrm{~s}$ to be noted that there is an outgtanding judgment of $\$ 70,000$ against the bank 1 th a $10 \%$ penalty and 1ntoreat. This fudgment wes obtainod in the loner courta and oue tained by tho Supreme Court in connoction with the bank's refueal to pay on doman to the executor of the estate of $C$ becanse of an indebtednogs to the benk of the X Co. a partnershlp composed of $\mathrm{C}$ et al and claiming an of feet. The bank has asked for a ner hearing in tho case and the matter is now pending."

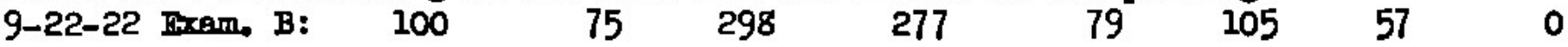

3-8-23 Fxam. B: "Jederal He日erve Bank ras paid by a new note on December 16, 1922 and has not been recalled. It ras necessery to rediscount bills recelvablo to extent of $\$ 46,950.00$ in order to pay off the claim of $\$ 84,845.01$ including interest and penelty to the C estate. The ehrinkage in deposits is due to the bank having logt the lawsult againat the $\mathrm{C}$ estate. Competition is keen between the two banks and a very unfriendly feeling existe."

3-8-23 Aram. B: $\quad 100 \quad 60 \quad 266 \quad 246$

$246 \quad 47 \quad 70 \quad 93$

0

9-25-23 traw. B: "There is unquest1onably a large amount of slow and doubtful assete in the bank, requiring most cereful attention. Iltigation on account of the $X$ Compeny contimues and 1t is about a fifty-fifty chance of wining in the end. Because of the litigation the bank has met with unfavorable outside comments and no doubt has lost some bueiness. All matters of criticism hare been incorporated in the report proper with a view to bringing the banis condition equarely before them. The cotton crop in this immediate vicinity bas fallen ahort of expectations and their hope now is in the present crop, which is reported above the average."

$\begin{array}{lllllllll}9-25-23 \text { man. B: } & 100 & 56 & 249 & 202 & 69 & 125 & 82 & 1\end{array}$

4-18-24 Bxam. C: "There has been no 1mprovement in the condtion or managoment sinco the last examination. Ho constructive attention has been given to elimineto the objectionable features reportsd in the eremination on sept. 25th. 1923. A major portion of the investments are highly unliquid as the $X$ Co.. and the large capital loans, those lines runing from $\$ 5,000$, and below up to $\$ 13,000,00$. It 
Case 6 (Contimzed)

Surplus

Date

Cape \& Brofita Loans Depogito 1nge Slor Doubtful Iopge日

Io merely a waiting proposition to detsrinine what the outcome will be with reference to these 1nvestments. The bank 1s finsucing the I company in the amount of $\$ 28,896.82$ in purchases in the form of acceptances or drafts, dramn on th1s concern at face value. The I Company 1s sald to be a corporation capitalized at $\$ 10,000.00$, the stock omned in equel parts by $\mathbf{A}$, Caghier, $0 . \mathbf{A}$, son of cashier, $D$, son-in-law of Caghter and $E$. The crope are not stored in an independent or bonded warehouse, but in the mill of the corporation and are therefore out of the possession of the bank and the advance would appear to be upon morel riak only, and constituting an excessive line. I Inspected the plant and found that there was on hand some crops in bage, and some in bulk. Wo way to determine except epprox1mately, the value on hand. A deposit of this concorn was carried on the individe al ledger amounting to $\$ 8,236.57$, representing, I was informod, the proceeds of the salo of a part of the original purchase of crope. There is no doubt that the bank is carrying contingent lossea in large amounts, in addition to tho contingent loss in the I Co. There ie rather defintte loss in the $F$ peper. It would appear to be extremely hazardous to advance this party additional funds. Thts paper should be accepted as a loss and cleared of $f$ the books before the close of the year. Tho brielness of the bank is running very light. One man could take care of the clerical part of the work. Four men rere on the pay roll on date of oxamination in eddition to Cashier A. I understand, however, that one man was temporarily employed."

4- 18-24 Bram. C: 100

$46 \quad 238$

215

70

109

98

9-25-24 Hram. C: Mrote the decline in deposits since the last examination and this in the face of the fact that cotton 1a moving freely and deposite should (normally) be materially increased. The large amount of contingent losses, one 1 tem of which 1a known by the general public to be in contest, and being delayed in adjudication for so long a time, is evidently having ite adverse effect upon the bank. This territory although adjolning one of the safest cotton producing sections of this state, is unfortunately located for the profitable production of cotton, the lande being more subject to the depredations of the boll wesvil than those fust south, and are therefore not at tractive for investment purposes. And it is of this property that the bank is so ebundently loaded in lother Real Fatate' and in loans upon the land, th a mere equity in most of these lands. Note the aggregate of olow peper, $\$ 104,437.63$, and of Doubtful, $\$ 77,618.67$ and the amount of lose charged off $\$ 12,738.33$. The bank benefits only to a limited degree from the generally good crops in thie section, for except in a few inotences, as crop 1mprovement over formor years is shared by those whose oblige tions are in the list of the slow and doubtful loans, especlally to the extent of lifting that paper out of the slow and doubtful colum. Mr. A hai been in bad hoalth for several months. He has been in bed for possibly throe weeks. I viaitod his home and went over the effalrs at the bank,"

9-25-24 Bram. C: $100 \quad 41244.195 \quad 102$

Receiver:

145

104

78

114 


$$
\begin{gathered}
-257- \\
\text { Case } 6 \text { (Contimed) }
\end{gathered}
$$

Dete

Surplus

Cape \& Profitg Ioang Deposite

Borrow- Classified Asseta

\section{$19191920 \quad 1921 \quad 1922 \quad 1923$ Total}

EARNITGS:

$\begin{array}{lrrrrrr}\text { Het Income (Grose Farnings less Bxponses) } & 21 & 10 & 8 & 8(I) & 3 & 34 \\ \text { Recoveries } & 0 & 0 & 0 & 0 & 0 & 0 \\ \text { Losses Charged Off } & 1 & 6 & 13 & 17 & 3 & 40 \\ \text { Assessments before Suspenglon } & 0 & 0 & 0 & 0 & 0 & 0 \\ \text { Bad Assots Purchesed by Stockcholders } & 0 & 0 & 0 & 0 & 0 & 0 \\ \text { Dividends } & 4 & 12 & 8 & 4 & 0 & 28\end{array}$

\footnotetext{
(1) Deflcit.
} 